cuan_1058 can2008.cls March 5, $2010 \quad 16: 4$

\begin{tabular}{|l|l|l|l|l|}
\hline \multirow{2}{*}{ aptara } & CUAN & cuan_1058 & Dispatch: March 5, 2010 & CE: N/A \\
\cline { 2 - 5 } & Journal & MSP No. & No. of pages: 28 & PE: Sarah \\
\hline
\end{tabular}

\title{
THE DOUBLE BIND OF AMERICAN INDIAN NEED-BASED SOVEREIGNTY
}

\author{
JESSICA R. CATTELINO \\ University of California-Los Angeles
}

Tribal gaming has changed the life fortunes of many but not all American Indians and realigned legal, cultural, and economic relations between indigenous and nonindigenous peoples. Much is new in this story, but much is not. At first glance, the wealthy "gaming tribe" fits Michael Fischer's concept of an "emergent form of life," insofar as it involves a sociality of action that cannot be understood within existing analytical concepts and political orderings, it presents vexing comparative and historical questions, and it poses ethical dilemmas for indigenous and settler publics (Fischer 2003:37). Rather than taking for granted that new forms of indigeneity are emergent in the gaming era, however, I ask a related set of questions that can reveal patterns in how indigenous economy, political status, and cultural difference are organized by settler societies: Why does indigenous wealth so often appear to be emergent in the United States relative to indigenous poverty? With what effects and antecedents? And what might this tell us about structures of expectation - especially economic ones - that face indigenous peoples in settler states?

Tribal gaming calls attention to the economic organization of indigeneity and, more generally, to the cultural politics of settler states. In this essay, I examine a double bind that faces indigenous peoples in the Anglophone settler states and that goes some way toward explaining why American Indian wealth often seems to be emergent. This is the double bind of need-based sovereignty. In the most general terms, this double bind works as follows: American Indian tribal nations (like other polities) require economic resources to exercise sovereignty, and their

CULTURAL ANTHROPOLOGY, Vol. 25, Issue 2, pp. 235-262. ISSN 0886-7356, online ISSN 1548-1360. (C) 2010 by the American Anthropological Association. All rights reserved. DOI: 10.1111/j.1548-1360.2010.01058.x 
cuan_1058 can2008.cls March 5, 2010 16:4

CULTURAL ANTHROPOLOGY 25:2

revenues often derive from their governmental rights; however, once they exercise economic power, the legitimacy of tribal sovereignty and citizenship is challenged in law, public culture, and everyday interactions within settler society. This is a double bind for indigenous peoples in the classic sense that competing possible paths to overcoming the dilemma negate one another, posing a contradiction and leading to no possible resolution. (The concept of the double bind reaches back to Gregory Bateson's theory of schizophrenia [1972].) ${ }^{1}$ Need-based sovereignty for indigenous peoples tellingly diverges from U.S. expectations that other sovereigns (e.g., European nations) will display — and be measured by - economic power. This double bind makes economy more central than often is realized to the practice, claims, and constraints of two forms of political status for indigenous peoples: sovereignty and citizenship. Still, “economy” alone cannot explain the phenomenon because economy-linked limits to indigenous sovereignty and citizenship, in turn, rest on debates over culture: on estimations of what it is that renders American Indians distinctive as individuals and as collectives and on culturally defined ideas of need that attach to individuals and collectives alike.

This essay addresses the double bind in two seemingly different but tellingly similar historical moments for the Seminole Tribe of Florida. ${ }^{2}$ First was the threatened "termination" of the Seminole Tribe of Florida as a governing body by the notorious 1953 federal termination policy that severed government-to-government relations between the United States and selected American Indian polities. One of the many criteria by which the federal government selected tribal nations for termination was economic capacity, and Seminoles struggled to assert a vision of economic well-being as consistent with collective governance. Second was the fragile assertion of Seminoles' gaming-linked economic and political power at the 2007 fiftieth anniversary of tribal reorganization. Since 1979, Florida Seminoleswho number approximately 3,500 tribal citizens, most of whom live on or near six discontinuous reservations in South Florida - have undertaken dramatic economic expansion and a single-generation shift from endemic poverty to economic comfort. This is the direct result of their historic foray into casino gaming. Images of Seminoles in local media have shifted from families dressed in distinctive bright patchwork clothing and men wrestling alligators for a scant living to luxury cars and the glitzy Hard Rock casino-resorts on the Tribe's urban Hollywood and Tampa reservations. As I have discussed in a book on Seminole gaming and sovereignty (Cattelino 2008), Seminoles assert that gaming wealth emerges from their sovereignty and facilitates its exercise through social service provision, natural 
citizens, cultural production, and an ever-growing array of governmental activities. Nonetheless, they struggle against legal, political, and cultural pressures that would view gaming wealth as negating sovereignty. American Indian tribes can undertake gaming only because of their sovereignty, and yet gaming wealth threatens to undermine that very sovereignty.

Anthropologists and other scholars have analyzed the ways that indigenous peoples must fit themselves into preconceived expectations by settlers to achieve recognition, including but not only federal recognition as tribal governments. One of those expectations is a level of distinctiveness and political continuity that would elude many other polities (see Blu 2001; Clifford 1988; Cramer 2005; Sider 2003). ${ }^{3}$ Elizabeth Povinelli further has argued that indigenous peoples consistently fail at difference and indigeneity because the inspection regime of recognition requires them to be radically different and yet, at the same time, cannot actually recognize radical alterity: "I suggest that this inspection always already constitutes indigenous persons as failures of indigeneity as such. And this is the point” (Povinelli 2002:39). ${ }^{4}$ Radical difference generates the perception of psychosis, but the lack of radical difference calls indigeneity into question (because if indigenous peoples are fully understandable, then they are not truly different, and therefore any rights based on their difference are suspect). What interest me are the economic dimensions of such double binds, where the issue is not simply the failure to be different enough but also the simultaneous unrecognizability of difference. Seminoles and other American Indians cannot assert economic power — which, importantly, is often gained only as the direct consequence of their collective status as governments - without being individualized as U.S. citizens (and, therefore, exposed to the allegation that they enjoy undeserved "special rights"). This is not simply a question of state extraction or protection of economic resources, nor is it a phenomenon entirely internal to capitalism. ${ }^{5}$ Rather, need-based sovereignty hinges on the cultural dimensions of economy as one way that peoples and polities mark difference. At stake are the economically and culturally differentiated possibilities of collective life within the political landscape of the United States. ${ }^{6}$

As Seminoles have found, indigenous wealth flies in the face of expectation in U.S. public culture. By this use of the term, I do not mean that every non-Indian holds a particular view of who and what Indians should be but, rather, that we can detect a pattern or structure of expectation in historian Philip Deloria's (2004) sense. In a collection of essays about "Indians in unexpected places"_playing sports, driving cars and using other technology, making music - Deloria asks his readers to understand expectation in the following way: "I want you to read it as a shorthand 
cuan_1058 can2008.cls March 5, 2010 16:4

CULTURAL ANTHROPOLOGY 25:2

for the dense economies of meaning, representation, and act that have inflected both American culture writ large and individuals, both Indian and non-Indian" (Deloria 2004:11). Deloria's focus is on popular culture, rather than economic status, but I am most interested in the way that he categorizes two human responses to acts and representations that fly in the face of expectation: "And I would, finally, like you to distinguish between the anomalous, which reinforces expectations, and the unexpected, which resists categorization and, thereby, questions expectation itself (Deloria 2004:11). If American Indians are expected to be poor, should we take gaming wealth to be unexpected (i.e., as affording the opportunity to alter patterns of representation and action) or to be anomalous (i.e., as reinforcing needbased sovereignty and the attendant cultural and policy expectation that legitimate Indians are poor)?

The answer depends not on the presence of wealth but on the ways that indigenous and nonindigenous people interpret and mobilize economic action. ${ }^{7}$ Tribal gaming has the potential to unsettle powerful and politically constraining expectations of indigenous poverty insofar as it strengthens tribal nations' control over their own representation, political power, and, most importantly, ability to self-govern on their own terms. This potential, not indigenous wealth per se, is emergent and is illustrated by Seminoles' allocations of gaming revenues and reflections on political organization. At the same time, with the sounds of termination echoing in gaming debates, it is possible to identify the reemergence of need-based sovereignty as a key modality of settler colonialism in the United States. 8

\section{TERMINATION}

In 1953, the U.S. Congress passed House Concurrent Resolution 108, commonly known as the termination bill, which sought cessation of the governmentto-government relationship between the United States and tribal polities. ${ }^{9}$ The government-to-government relation had been grounded in treaties, the U.S. Constitution, and a history of political relations between the various indigenous nations and the United States (Deloria and Lytle 1984). Termination would obliterate tribal sovereignty in the name of individualized U.S. citizenship for American Indian people. Termination - which is widely understood to have been a postwar rejection of the Indian New Deal policies of John Collier, the Left-leaning Commissioner of Indian Affairs - went hand in hand with an urban relocation program that would 
A major (but by no means exclusive) criterion by which policymakers identified tribes as good candidates for termination was a thriving economy. Termination policy specified that "advanced" tribes with "economic capacity" should no longer have a collective relationship with the United States (Philp 1999:71, 158). ${ }^{11}$ Economic power undermined tribal sovereignty and collective governance, even though it often derived from them. Although in the end only a handful of tribal nations were "terminated," with ensuing land loss and social fragmentation, the episode marks an important moment in American Indian history when indigenous political and economic difference were reckoned on cultural terms.

\section{Terminating Governance}

A few words on sovereignty are in order, because termination aimed to eliminate American Indian polities. For the purposes of this essay, I take indigenous sovereignty (called "tribal sovereignty" in the United States) to be the authority and obligation of people within an indigenous polity to determine the extent and nature of their governing authority with regard to their territories and one another. Tribal sovereignty, as asserted by indigenous groups and often but not always recognized by the United States, forms the basis for government-to-government relations among the tribes and between each of them and the U.S. federal government (Wilkins and Lomawaima 2001; see also Barker 2005; Biolsi 2005; Deloria 1979; Deloria and Lytle 1984). American Indian governments hold authority over a range of governmental activities in areas that include the determination of citizenship, the regulation of on-reservation commercial activities (such as gaming), varying levels of criminal jurisdiction, natural resource management, child welfare and social service provision, and more. Sovereignty, which has been limited but not extinguished by the United States, has become a catchword of American Indian rights movements since the 1960s (Wilkinson 2005), and today it is the legal framework for most American Indian rights claims. Sovereignty is material, not only insofar as it is based in land and control over resources but also because sovereigns require revenue for their operations and because those operations generally include resource allocation and regulation. That economic capacity was a criterion for termination is a paradox insofar as a commonly recognized marker of sovereignty in international contexts led to its cessation for indigenous polities.

Florida Seminoles often understand their sovereignty to emerge from three sources. The first is their precolonial and ongoing governmental authority, whether they locate that authority in the democratically elected and reservation-based Tribal Council or in ongoing matrilineal clan authority or in the legal and political power 
of the widely attended annual Green Corn Dance ceremony. Second is their victory over the United States military during the long and bloody 19th-century Seminole wars and subsequent hard-fought independent life in the Florida Everglades. That victory is celebrated in tribal school curricula, battle reenactments, child naming practices, traditional medicine, and Seminoles' self-designation as "the unconquered." 12 Third, and more diffuse, is the ability to live a distinctive kind of life on their own terms, whether that means listening to the quiet of the swamps on the Big Cypress Reservation, cattle ranching on the prairies of the Brighton Reservation, heeding advice from maternal uncles, practicing Southern Baptist Christianity or "traditional" religion, attending countless tribal social and health-related activities, or simply living life as a Seminole with kith and kin. ${ }^{13}$ "Sovereignty" is an increasingly common word in Seminole discourse, and it often arises as the foundation for - and endpoint of - gaming.

To widespread surprise, Florida Seminoles were slated for termination in 1953 (Kersey 1996). No previous list of groups likely to be terminated had included Seminoles, and in fact they had been listed in the category of tribes that most needed federal assistance and therefore were least appropriate for termination (Kersey 1996). ${ }^{14}$ Only during the 1930 s had Seminoles, with an estimated population of 1,000 , begun to move in significant numbers from scattered swamp and prairie settlements to three new federal reservations, where some entered federal employment. Seminoles comprised two language groups (Mikasuki and Muskogee), lived in matrilineal clan-based camps of thatched-roof chickees, resisted centralized government in favor of decentralized clan-based legal authority, participated in tourism and some forms of wage labor but more often than not withheld youth from "white" schools, and were increasingly divided over matters including a 1940s federal land claim and Christian conversion. ${ }^{15}$ By the 1950s, Seminoles had become poor, they received little in government funds $(\$ 137,000$ annually, mostly for road building [Kersey 1996:28]), and they lived with little federal oversight by comparison to most of Indian Country. These factors made Seminoles an unlikely target of termination, although lawmakers and executive branch officials lauded Seminoles for being "very independent" and having "taken care of themselves until rather recently" (U.S. Congress 1954:1054), and they praised Seminole families for being self-sufficient, rather than depending on federal funds (U.S. Congress 1954:1030, 1032). Termination, these lawmakers hoped, would prevent dependency.

Almost all Seminoles opposed termination, despite raging internal political conflicts about whether and how to engage with the federal government, and 
historian Harry Kersey Jr. (1996) has documented their efforts to fight it. ${ }^{16}$ To this day, in speeches at tribal events and in interviews, Seminoles recall holding the first all-Indian rodeos (now rodeos are part of the fabric of reservation life) as fundraisers for a road trip to testify against termination in 1954 joint congressional hearings in Washington, D.C. A 2009 exhibit about cattle ranching at the Tribe's Ah-Tah-Thi-Ki Museum highlighted the role of rodeo in this political battle. A year later, they hosted visiting members of U.S. Congress at two South Florida hearings. Then, as now, Seminoles opposed unwelcome federal involvement by embracing the legacy of their ancestors' resistance to federal incursion and recounting the 19th-century Seminole wars.

\section{Economic Citizenship in the Settler State}

If collective economic power undermined indigenous governance in the termination era, it also was unrecognizable in many termination advocates' eyes because they understood wealth to be the foundation of, and evidence for, individualized economic and political assimilation that would reorient individuals' relation to the settler state. Termination shifted the terrain from sovereignty-polity to citizenship-individual, with citizenship figured not in relation to the indigenous nation but, rather, to the settler state. With passage of the Indian Citizenship Act of 1924, all American Indians were granted nonexclusive U.S. citizenship, whether or not they wanted it, and despite efforts by some to refuse it. ${ }^{17}$ The termination of indigenous sovereignty via the dismantling of tribal governments was inextricably intertwined with a focus on economic contribution as the measure of individual (U.S.) citizenship.

The citizenship status of indigenous individuals in liberal settler states poses a fundamental dilemma: how can nation-states that commit to equality among the citizenry take account of the differential political status of indigenous peoples as citizens both of indigenous polities (e.g., the Seminole Tribe of Florida) and of settler states (e.g., the United States)? Scholars have examined this dilemma with regard to political rights and legal claims (Kymlicka 1995; Maaka and Fleras 2005; Paine 1999; Peterson and Sanders 1998; Povinelli 2002), and Thomas Biolsi (2005), among others, has analyzed the "hybrid political space" of dual citizenship. Fewer have explored the economic dimensions of citizenship - or what T. H. Marshall (1992) famously named "social citizenship"-for indigenous people. Those who have done so usually note that indigenous citizenship in settler states often is organized by need. Jeremy Beckett (1988) and Robert Paine (1977, 1984), among others, have developed the concept of "welfare colonialism" to characterize the 
cuan_1058 can2008.cls March 5, $2010 \quad 16: 4$

CULTURAL ANTHROPOLOGY 25:2

ways in which aboriginal citizens are addressed as needing service provision and thereby occupy subordinate positions in settler states. ${ }^{18}$ Taken together, American Indians remain the poorest ethnic-racial group in the United States, despite recent gains from gaming profits (Taylor and Kalt 2005), and the bureaucratic production, assessment, and meeting of need have been occasions for many indigenous individuals to encounter the state. This helps to explain why some termination supporters, including a few Indian advocacy groups, took the governmental relationship to be one not of sovereign recognition but, rather, of destructive paternalism (embodied by supervisory reservation-based "Indian agents"). ${ }^{19}$ The absence of need, however, has the potential to render indigenous polities unrecognizable to the state. One example of this double bind was the federal determination of Indian eligibility for U.S. citizenship based on economic competence (often but not only coded by categories like "mixed blood") during the implementation of the General Allotment Act (Dawes Act) of 1887. Tellingly, the Dawes Act stipulated that the acceptance of U.S. citizenship, with allegiance sometimes ritually sworn on a plow handle, required severing political allegiance to tribal governments. Teddy Roosevelt famously promoted allotment as "a mighty pulverizing engine, to break up the tribal mass" (Wilkinson 2005:43).

Today, Seminoles live at civic boundaries when they decide whether or not to vote in tribal and extratribal elections, when they cheer on Florida college football teams, and when they honor U.S. military veterans. ${ }^{20}$ Less obviously, they also do so when they decide whether or not to hang "Seminole Indian" license plates on their vehicles and risk them being keyed in parking lots, when Seminole women decide whether to take husbands' surnames, when non-Seminoles ask how they can sign up for tribal membership on learning of gaming-generated benefits, when Seminole leaders serve on regional tourism boards and other governing bodies, and when all Seminoles answer for the millionth time whether they pay taxes (yes) or just how much they receive in gaming-based per capita payments from the tribal government (the number is rarely disclosed). ${ }^{21}$

During the termination hearings, evidence of Seminoles' economic capacity and market integration coded them as (productive) U.S. citizens, "ready" for termination and equal status with non-Indians, while glaring economic need was cited by termination opponents as justification for ongoing tribal governance. The focus on civic egalitarianism was not unique to the Seminole hearings; indeed, the termination bill's stated goal was: "to make the Indians within the territorial limits of the United States subject to the same laws and entitled to the same privileges 
their status as wards of the United States, and to grant them all of the rights and prerogatives pertaining to American citizenship" ([H. Con. Res. 108] 67 Stat. B122). ${ }^{22}$ Becoming full citizens (recall that American Indians already were citizens under the Indian Citizenship Act of 1924) entailed no longer being wards, a term that referred to the Marshall U.S. Supreme Court opinions of the 1830s categorizing Indian tribes as "domestic dependent nations," "in a state of pupilage" wherein "their relation to the U.S. resembles that of a ward to his guardian" (Cherokee Nation $v$. Georgia 1831, 30 U.S. [5 Pet.], 16-17).

Foremost among the responsibilities that Indians would assume with termination was to contribute as proper economic actors. American Indian individuals were encouraged to take up new economic lives, and collective lands would convert to individual property ownership; some tribes were targeted for relocation to join the urban industrial labor force. There was some ambiguity about Seminole individualization when lawmakers suggested that Seminoles could create a posttermination private corporation to hold their lands. Officials insisted, however, that Seminoles henceforth would be treated as individual citizens, not a governmental entity, regardless of whether they formed a corporation, and they understood that collective assets would be sold off (U.S. Congress 1954:1058). ${ }^{23}$

Questions and testimony on both sides were shot through with a modernist rhetoric of Indian progress that hinged economic participation to U.S. citizenship. For example, a local non-Indian advocacy group, The Friends of the Seminoles (whose leadership included prominent Fort Lauderdale store owners who traded with Seminoles), issued the following statement endorsing Seminoles' request to delay termination for 25 years: "This time is necessary for the education and experience of the youth of the Seminole Nation so that they may learn the English language and the white man's ways, and be fitted to take their rightful place in our American way of life and as useful citizens of Florida" (U.S. Congress 1955:12). Here, citizenship entailed assimilation to the “white man's ways," implicitly through economic contributions ("useful citizens"), but this required interim federal support. A local Congressman, who supported Seminole resistance to termination, took the position that full U.S. citizenship would have to be put on hold: "I know that the Seminoles themselves do not want the responsibilities of citizenship thrust upon them at this time" (U.S. Congress 1954:1132). He worried that Seminoles were not ready to manage property because of "ignorance of ownership of real estate" and taxes, because they were not equipped to take jobs in the "white economy," and because they were not literate or educated. To be a fully progressed U.S. citizen, agreed many termination advocates and opponents alike, required 
entering the "white economy." Indigenous economic success was a mode and sign of whitening. One corollary was that citizenship in an indigenous polity was to be surpassed; another was that "real" Indians remained poor. ${ }^{24}$

Some Seminoles adopted the language of economic progress and requested ongoing federal supervision. Yet, witnesses did not envision an economic telos that ended with assimilation. Laura Mae Osceola, a translator who later became a member of the Seminole Constitutional Committee and founded the Miss Seminole pageant, argued against termination within its economic logics, casting her reasoning in need-based terms by stating that Seminoles were not yet ready for termination. Yet her confidence in — and commitment to-Seminoles' future economic power and ongoing cultural cohesion became clear when she promised a Congressman that “in 25 years more they won't need your help. We will be giving you help" (U.S. Congress 1954:1122). Mike Osceola, a businessman whose commercial acumen drew praise from federal officials, was a rare and controversial Seminole termination supporter. After his remarks, which emphasized ending federal paternalism, one enthusiastic senator interpreted Osceola's termination advocacy to mean that he would favor Seminoles' assimilating with the white people of Florida. But Osceola replied: "I don't know just what particular reference you have, 'assimilating.' Not necessarily. They [Seminoles] can live on their own camps or where ever they want to live” (U.S. Congress 1954:1067). For Osceola, unlike for many of his non-Indian protermination allies, the full exercise of U.S. citizenship was compatible with cultural distinctiveness.

Other Seminoles shared termination proponents' critique of governmental paternalism and testified that they wanted the federal government to leave them alone, but even these individuals did not equate autonomy from governmental oversight with individualism and the cessation of indigenous governance. Buffalo Tiger, for example, testified that his off-reservation group, who resisted residing on federal reservations and who subsequently organized as the Miccosukee Tribe, sought neither money nor supervision from the United States but instead simply hoped to hold onto their Everglades homelands, where they could live and hunt. He was asked whether, in that case, each person would want an individual plot of land. Tiger replied: "No; they don't want it that way. They don't want it. They want the tribal council should have the land so that all of us can live on it and all hunt on it. They don't want chopped up” (U.S. Congress 1955:49). Tiger, who would go on to serve as Miccosukee tribal chairman, was not alone in upholding collective governance. As Kenneth Philp has shown, during the 1940s 
simultaneously achieve individual first-class U.S. citizenship and also maintain the institutions and powers of tribal governments (Philp 1999).

Only Henry Cypress went so far as to advance the view that the federal government should provide for Seminoles not as a welfare-based entitlement but, rather, as an obligation that results from indigenous dispossession. He said: "As far as we know, when we look back in the history, your forefathers fighting for the country, and you got it now, and we got a little piece of land on the reservation. Therefore, the Government supervision to help us should continue” (U.S. Congress 1954:1147).

\section{Sovereignty as Wardship}

The role of economy in termination reveals a fundamental tension in federal Indian policy during the midcentury, one revisited in the gaming era. This is over the question of whether the federal government's relationship with indigenous polities is based on need, wardship, and supervision, on the one hand, or sovereign recognition and a trust relationship, on the other hand. This tension was reflected in lawmakers' arguments over the goals of their own policy: at one telling moment in the Seminole hearings, lawmakers sparred over whether the status quo resembled the Marshall Plan for Europe (Kersey 1996:30). Was "federal supervision" comparable to the dole, or was it more akin to the support provided by one government for another government as it (re)built and (re)established independence?

As with many other tribes (Wilkinson 2005:86), Seminoles responded to the threat of termination by asserting their self-governance. They were removed from the termination list, and, in 1957, groups living on reservations and their allies reorganized their tribal government into two elected bodies, a tribal council to handle governmental affairs and a federally chartered corporation to manage businesses. This reorganization secured their formal recognition as a government by the Bureau of Indian Affairs, and recognition afforded Seminoles both legal protections and federal services. The costs were high, however. Seminoles disagreed about the wisdom of solidifying ties with the federal government, and the political rift led to the separate organization of Miccosukees (who were federally recognized in 1962) and Independent Seminoles (who refuse federal recognition to this day). Reorganization introduced new bureaucratic governing forms, diminished the power of clan councils (although clan remains salient in political practice), and led to a period of heavy federal presence on Seminole reservations (Cattelino 2006; Kersey 1996). Poverty grew with Everglades drainage, high unemployment rates, increased consumer needs, and growing health concerns. Various federal programs 
cuan_1058 can2008.cls March 5, 2010 16:4

CULTURAL ANTHROPOLOGY 25:2

and individual entrepreneurial efforts - from cattle ranching to light manufacturing, craft sales to land leases_-yielded paltry income. Seminoles' reservation lands were secure, unlike lands lost by terminated groups, but because reservation land is inalienable, Seminoles had little collateral and few opportunities to build equity. Moreover, for reasons of racism and business alike, few lenders other than the federal government would invest on the reservations. For a time, it appeared that by avoiding termination Seminoles had secured limited rights to self-government, but with the cost of deepening poverty.

\section{GAMING AND CONSTITUTION}

Expectation

Approximately 25 five years after successfully fending off termination, and therefore right on time by Laura Mae Osceola's prediction, the Seminole Tribe of Florida in 1979 exploited their governmental freedom from state regulation by opening the first tribally operated high stakes bingo hall in Native North America. ${ }^{25}$ In federal court Seminoles successfully defended the position that states have little authority to regulate on-reservation business activity by tribal governments, and because gaming is such a highly taxed and regulated industry this affords tribal governments a significant competitive advantage. ${ }^{26}$ Seminoles pursued gaming as an act of self-government; as such, the "gaming tribe" emerged at the intersection of indigenous sovereignty claims with economy, well before federal policy regulated gaming with the 1988 passage of the Indian Gaming Regulatory Act (IGRA). Thus began the tribal gaming era, as other American Indian governments followed suit and American individuals, states, local municipalities, businesses, and the federal government grappled anew with the cultural and political implications of indigenous wealth. Still, echoes of termination sound loudly in gaming debates, suggesting that gaming is not a progressive tale that culminates in tribal self-determination. ${ }^{27}$ Rather, gaming wealth has prompted many observers to question the validity of indigenous "special rights" and cultural distinctiveness.

Florida Seminole casino revenues, currently approaching \$1 billion annually, have dramatically affected tribal citizens' lives. As discussed elsewhere (Cattelino 2008), gaming revenues have been allocated to build a robust social safety net, from universal health care to a charter school on the Brighton Reservation; gaming money funds cultural programs, from language education to a tribal museum on the swampy Big Cypress Reservation; and economic diversification initiatives (e.g., cattle ranching and citrus growing, convenience stores, venture capitalism, 
distributions of gaming revenues to each tribal citizen. In the gaming era, Seminoles debate Tribal Council and individual spending, worry about how to raise children who will value hard work, and scramble to assure that financial literacy and political process keep pace with growing revenues.

The economic power of gaming, at first glance, makes the threat of termination seem to be but a distant memory. After all, Seminoles now exercise unprecedented political power in the hallways of state and national capitals, where they hire lobbyists and build personal relationships with legislators. They have built a formidable legal team to defend their sovereignty-based rights, they have few of the disputes over tribal membership that have divided other American Indian communities, they maintain valued social and cultural practices that distinguish them from non-Seminole Floridians, and their economic reach has extended to all corners of the earth with the purchase of Hard Rock International and its global network of cafés. But, just as indigenous economic "success" — often measured by assets and market integration — was for many termination-era observers a mark of assimilation, so too do casino capitalism and resulting wealth threaten American Indians' present-day claims to political and cultural distinctiveness. They do so in at least three ways.

First, there has been a dramatic increase in non-Indian public criticism of tribal gaming as an example of unjust "special rights." Joanne Barker (200506), Katherine Spilde (2004:75-81), and Eve Darian-Smith (2003) have begun the important work of documenting the growth of antisovereignty movements that have arisen in response to gaming. ${ }^{28}$ Notably, tactics by such groups and by individuals include allegations of indigenous greed and disproportionate wealth. As political scientist Kevin Bruyneel suggests, public criticism of gaming positions economic power as temporally associated with the future, whereas tribal sovereignty is relegated to the past: "By succeeding economically the tribes temporally outpaced their claim to sovereignty, while still being seen as somewhat alien to American political life" (Bruyneel 2007:190). ${ }^{29}$ Seminoles' economic power has sparked less organized antisovereignty activism than elsewhere, but with gaming wealth has come increased public skepticism of whether Seminoles "need" so-called "special rights" in law enforcement, gaming, and other arenas (see Cattelino 2008).

Second, federal law and policy increasingly treat gaming success as justification for undermining the very foundations of tribal sovereignty. Spilde gives the example of Minnesota fishermen who in a U.S. Supreme Court case opposed Mille Lacs Band of Ojibwe treaty rights on the ground that tribal members now held casino jobs (Spilde 2004:78). A 1998 Supreme Court ruling cited gaming 
cuan_1058 can2008.cls March 5, $2010 \quad 16: 4$

CULTURAL ANTHROPOLOGY 25:2

and cigarette sales when suggesting that indigenous commercial success might be cause to abrogate tribal sovereign immunity in the future (Wilkins and Lomawaima 2001:230-231). ${ }^{30}$ Proposals occasionally pop up in U.S. Congress to assess the federal obligation to individual tribes not on the basis of treaty rights or sovereign recognition but, rather, by “means-testing," whereby federal allocations would be measured by an indigenous group's financial "need.” Legal theorist T. Alexander Aleinikoff observed that gaming wealth threatens sovereignty because some lawmakers hold that "the increasing wealth and sophistication of the tribes argue for their assimilation and the ending of special Indian programs. To adopt the language of the late nineteenth century, Indians no longer need the guardianship of the federal government" (Aleinikoff 2002:123). Gaming has revived need-based sovereignty.

Third, need-based sovereignty in the casino era also and always is about culture and about the surprise value of indigenous wealth. I am frequently asked by nonIndians whether gaming wealth leads to indigenous cultural loss. In part, gaming debates take a cultural turn because, as anthropologists have widely documented, economic activities are often understood by social actors to be markers of cultural difference (Sahlins 1993). But this is particularly potent for indigenous peoples. At least since Lewis Henry Morgan based his evolutionary theory of economic stages on research with the Iroquois (1974), American Indians have been positioned in scholarly and public discourse as being outside of - and, more precisely, as prior to- "advanced" economic life in general, and capitalism and the use of money in particular (see also Dombrowski 2001). ${ }^{31}$ The end result, as legal scholar Sam Deloria notes briefly in a larger critique of the concept of cultural sovereignty, is a unique standard of poverty and cultural difference by which indigenous sovereigns are measured: "Nobody visits Liechtenstein periodically to make sure they are sufficiently poor and sufficiently culturally distinct from their neighbors to merit continued political existence. They're just around" (Deloria 2002:59). In the casino era, American Indians once again encounter the economic politics of settler colonialism, in which it is only a short step from wondering whether Indians with gaming are losing their culture to skepticism over whether indigenous people with economic power can and should remain legitimately indigenous and sovereign.

\section{Refusal}

On August 21, 2007, Seminoles celebrated the fiftieth anniversary of their governmental reorganization with a daylong celebration on the Hollywood Reservation. Events for the 1,000-plus mostly Seminole attendees took place in three 
day began with a morning press conference under the historic Council Oak, the majestic tree — now surrounded by a casino parking lot and smoke shop-under which the original constitution signing had taken place. Although the press was invited, the tenor of the event more closely resembled the many community-focused celebrations and political events that I had attended since first undertaking research on Seminole gaming in 2000. In fact, most elected officials delivered at least some of their remarks in Mikasuki or Muscogee, often without translation for the press and the many attendees (Seminole and non-Seminole alike) who could not understand one or both of the indigenous languages. Next, the invited participants - tribal citizens and their personal guests, VIPs including visiting leaders of American Indian nations and the president of Florida State University - gathered in a massive tent erected on the Hollywood Hard Rock casino parking lot to eat a noontime dinner and watch a fashion show of Seminoles' signature patchwork clothing. Finally, we settled into stadium seats at the Hard Rock Live! auditorium and enjoyed complimentary snacks while viewing a tribally produced documentary film screening followed by a live theatrical production with Seminole actors. Throughout the day, morality tales of survival despite economic hardship intertwined with a critique of termination policies to situate the present-day tribal government at the triumphant convergence of political and economic power. The events, which had a distinctly pedagogical tone, crystallized Seminoles' often more quotidian refusals of the economic logics of termination by staking a public claim for collective governance through, not despite, wealth and market integration.

After a prayer and children's Muskogee-language recitation of the pledge to the Seminole flag, press conference emcee Moses Jumper Jr. declared the day to be the anniversary of when the United States government "officially, through the U.S. eyes, designated us as a tribe." He and others positioned the 1957 reorganization not as the founding Seminole political moment, which is how it was covered by local media, but, rather, as a time when Seminoles achieved outside recognition of their already-existing governmental authority. Or as Board of Directors President Richard Bowers reminded the assembled: "we have long since been here, long before fifty years." This was a curious event, in which the speakers disavowed the significance of the very documents they commemorated and in which they celebrated but also refused the terms of recognition.

Tribal Council representative Max Osceola Jr. (Laura Mae's son) began by thanking the "Seminole warriors from the 1800s who told the federal government during forced removal that 'we're not going to Oklahoma." Osceola traced this thread of refusal forward in time to termination, explaining that "they were going to 
legislate us out of existence." He recalled telling a reporter that the Seminole Constitution resembled the U.S. Constitution, because both established independence from another power. Yet, he asserted, "Seminoles didn't have to have a constitution to have a government," and he listed off the signs of prior self-governance, from a functioning traditional medical system to political organization. (At one point Osceola referred to a time "BC," then paused to explain with a chuckle that he meant "before Columbus." A subsequent speaker, O. B. Osceola Jr., drew laughs when he referred to "BC . . . before casinos." Neither defined BC as "before the constitution.") In the end, Max Osceola said, the constitution "does not define Seminoles." Seminole governance, for Osceola and others, existed prior to and outside of the terms of U.S. federal recognition. The constitutional moment was less one of founding than one of refusal, the refusal of termination. Thus, the constitutional tribal government and corporate charter, not to mention the gaming revenues that they enabled, are punctuation marks in a long chapter of ongoing refusal and indigenous reemergence.

Speakers in the pageant (who were scripted) and the film (who were not, and who included many nonpoliticians) similarly cast political recognition and constitutionalism less as originary than as a plucky response to the threat of termination. This pluck had been materialized, viewers learned, in the rodeo they held to fund the delegation's travel to testify in Washington, in the baloney sandwiches they packed for the road, in the borrowed car they drove. Pluck also characterized the subsequent bold move to pursue gaming. Such boldness made leaders. Thus, another effect of the event was to reinforce the political incumbency by connecting this narrative of leadership and refusal directly to the present regime. As Tina Osceola, Museum Director, said during the press conference: "Honor those who dared to stare in the face of termination and said 'no more.' Honor today's leaders who stare in the face of federal policy and say 'no more." But to what did she refer?

To answer, we must return to economic hardship and need. As planning committee member Sally Tommie had repeated during anniversary planning meetings and again during the dinner and fashion show, most Seminole children today "never knew a life before luxury." Tribal citizens contrasted present-day pleasures with past suffering. For example, several people joked about how yesterday's dugout canoes or rusty cattle trucks were today's SUVs and BMWs; elected representative Roger Smith cracked a joke about today's steakhouses being yesterday's government surplus commodity food supply. Guests' anniversary gift bags were filled with standard corporate fare - a commemorative mug, medal, and glossy 
also contained a curious object: a small burlap sack with accompanying text that recounted Seminoles' past economic hardship, thrift, and ingenuity. The event's commingling of corporate opulence with homespun aesthetics and a strong sense of history reinforced speakers' insistence on joining wealth with tradition, and tying each to governance.

Throughout the day, references to political refusal structured the otherwise progressive narrative of overcoming economic hardship through gaming. That is, the constitution and charter, on the one hand, and tribal gaming, on the other hand, are not simply political and economic narratives of triumph. Rather, they operate together for Seminoles to position wealth as the outcome of political refusal, and wealth as fostering not individualized assimilation but collective self-governance. It is in the ongoing assertion of collective self-governance that we can identify Tina Osceola's call to honor today's leaders for saying "no more." In an email exchange long after the event, I asked Osceola what she had meant, and she replied: "I was referring to federal policies on gaming, sovereignty, the environment, health care, you name it - Most importantly it was about taking control of our destiny by defending and defining sovereignty our way!" (personal communication January $26,2009)$. This celebration was less about recognition than about carving out an economically viable space for the practical exercise of sovereignty in Seminole Country.

These events, like everyday Seminole practices that range from military participation to sports fandom, also rejected the termination-era logic whereby U.S. citizenship for American Indians required assimilation and severance from collective indigenous belonging. Throughout the day, flags flew high that represented the Seminole Council, the Seminole Board, the United States, the State of Florida, and the POW-MIA. Seminoles laid claim to multiple polities, rather than equating full U.S. citizenship with severance of tribal citizenship. The commemorative anniversary book honored Seminole entrepreneurs, folding individual economic initiative into a collective past, present, and future; it connected tribal government wealth from gaming with individual economic participation instead of opposing governmental to individual economic life. All of this could not be further from the civic logics of termination and need-based sovereignty. What's more, in frequent references to the Seminole Tribe of Florida's 2007 acquisition of Hard Rock International, the largest-ever purchase of a multinational corporation by an indigenous nation, attendees were reminded that Seminoles' collective economic and political projects are expansive, now stretching beyond U.S. borders across the globe. Throughout the day, several speakers had encouraged children to think big and plan 
for what they would celebrate at the 100-year anniversary. Max Osceola looked out from the stage over rows of seated schoolchildren, smiled impishly, and said: "Maybe next time we're up here you'll buy Disney World ... put some patchwork on it."

\section{CONCLUSION}

There is no easy escape from a double bind. At their anniversary celebration, Seminole speakers undertook one attempt by offering a triumphant narrative that conjoined indigenous sovereignty with wealth and cultural continuity. This is a necessary but also risky move. Risks become apparent when, for example, local newspapers in Florida and elsewhere interpret indigenous cultural claims as mere smokescreens for gaming-based, interest-group activity and, in turn, cast suspicion on a wider range of indigenous claims and groups. Another risk is that celebrating the triumph of casino capitalism drowns out indigenous critiques of gambling and of consultants' boilerplate recipes for "economic development." The double bind of economy and sovereignty for indigenous peoples cannot be outrun by throwing money at it, even though governmental revenues have the potential to strengthen communities and defend attacks on sovereignty. Instead, the double bind must be refused by reorganizing the cultural expectations on which it rests and by attending to the lived practices by which indigenous people enact sovereignty.

How can we distinguish the unexpected from the anomaly - or the disruptive opening to change from the outlier that reinforces the order of things - in contemporary settler society? It may be impossible to fully untangle the structure of expectation except with a retrospective view. That said, Gregory Bateson's original discussion of the double bind - despite its topical and theoretical distance from my own analysis - offers two clues as to when the double bind might unravel. One is his claim that individuals caught in double binds cannot comment on the impossibility of the contradictory demands placed on them: they cannot make metacommunicative statements (Bateson 1972:208). Another way to think about the communicative dimensions of double binds is that people caught in them cannot control the terms of their own representation. In such a context, refusal and rearticulation become critical. In the gaming era, most Seminoles insist on not only the compatibility but, even more, the interdependency of collective governance with (group and individual) economic power. This insistence is amplified by the Seminole Tribe's new gaming-based power to self-represent through tribal media, hired talking heads, press releases, and gatherings like the anniversary 
potential for need-based legal curtailments of sovereignty, Seminoles comment on contradictions (Bateson 1972:209), and they do so in ways that buttress internal self-governance and ways of living. To be clear: it is not simply that with money comes voice, because the double bind of need-based sovereignty offers evidence that the opposite can occur. Rather, reorganized social and cultural relations in the gaming era have opened new spaces of analysis and refusal. Indigenous peoples' refusals of contradictory claims take many forms, and gaming is by no means their sole context. Other examples include historical rejections of termination or citizenship conferral; everyday refusals of state authority in acts such as Mohawk border crossing, as analyzed by Audra Simpson (Simpson 2003); methodological and ethical refusal to "write in" what others claim they "need to know" (Simpson 2007); or the refusal of "help" offered by settler governments (Cowlishaw 2003). ${ }^{32}$ The achievement of refusal and its embodiment in everyday life are not to be taken for granted. Whether refusal of need-based sovereignty in the gaming context will be recognized in settler society is another question, and Povinelli's analysis offers a sobering account of recognition's perils; on that question, the jury is still out.

A second clue from Bateson concerns creativity. Double binds can and do produce severe pain, he argues, but if this can be "warded off or resisted, the total experience may promote creativity" (Bateson 1972:278). This point goes to Philip Deloria's distinction between the unexpected and the anomaly, where the unexpected leaves room for creative recategorization but the anomaly reinforces the order of things. ${ }^{33}$ My citation of creativity should not be mistaken for an apologist's stance: I wish to keep the analytical lens trained on understanding the double bind and its costs, rather than on its creative potential. Nonetheless, because needbased sovereignty relies on cultural markers of the relationship between economic and political difference, it is important to mark creative realignments of those markers as opening the possibility for different futures. Cultural politics are not merely produced by the political economy of need-based sovereignty or by the political structure of democratic states that seek to manage differences among citizens and polities. Rather, they are resources and methods by which political and economic relations come into being and perdure, and, in the context of needbased sovereignty, they are mechanisms by which settler societies legitimate their self-consciously modern economies and states. The contradictions of need-based sovereignty have variously shaped Seminoles' forays into gaming as a nationalized industry, their locally oriented determinations of how to allocate gaming revenues, and a host of other decisions. Insofar as these decisions open up space for indigenous 
cuan_1058 can2008.cls March 5, $2010 \quad 16: 4$

CULTURAL ANTHROPOLOGY 25:2

creativity, they may unsettle anomaly in settler states and occupy the space of the unexpected.

As for the role of scholarly analysis in unsettling the double bind, one place to start is by challenging the perceived newness of the "gaming tribe" as an emergent form of indigeneity by acknowledging that surprise at indigenous wealth has a long and troubling history. ${ }^{34}$ The double bind of need-based sovereignty for indigenous peoples is not universal across space or through time, but it is a modality of settler colonialism that has a variety of patterned effects. Among them are the unique barriers that face American Indians who attempt to gain economic power while insisting on their political and cultural Indianness. Corollaries include the weakening of indigenous sovereignty by its association with need, the consolidation of indigenous citizenship as failure because "successful" economic citizenship is coded as assimilation, and the recategorization of economic transfers based on treaty rights and federal-tribal trust relations as welfare benefits (and of indigenous citizenship as wardship). Taken together, these effects undermine indigenous economic and political power alike. Gaming wealth may be unexpected, but we should not take it to be anomalous, lest such an assessment turn into a self-fulfilling prophesy. Unsettling expectation by accounting for its history, force, and effects can go some small way toward untangling the double bind of need-based sovereignty.

\begin{abstract}
This essay examines a double bind that faces indigenous peoples in the Anglophone settler states, the double bind of need-based sovereignty. This double bind works as follows: indigenous sovereigns, such as American Indian tribal nations, require economic resources to exercise sovereignty, and their revenues often derive from their governmental rights; however, once they exercise economic power, the legitimacy of indigenous sovereignty and citizenship is challenged within settler society. Through analysis of Florida Seminole gaming and the threatened severance of Seminoles' governmental status by mid-1900s federal "termination" policy, I show how economy-linked limits to indigenous sovereignty and citizenship rest on debates over culture, over what it is that renders American Indians distinctive as individuals and as collectives. Today, as during termination debates, Seminoles and other American Indian peoples struggle to position their economic wellbeing not as an anomaly or an abandonment of indigenous ways but, rather, as the result of an ongoing commitment to collective self-governance. With the sounds of termination echoing in gaming debates, it is possible to identify the reemergence of need-based sovereignty as a key modality of settler colonialism in the United States.
\end{abstract}

Keywords: settler colonialism, indigeneity, tribal gaming, American Indian termination, economy, sovereignty, citizenship 


\section{NOTES}

1. Unlike Bateson, I am less concerned in this essay with psychological aspects of the double bind (much less with family relations) than with some of the formal characteristics of collective dilemmas that are posed by a double bind on a larger scale.

2. This discussion is based on ongoing research with the Seminole Tribe of Florida that began with yearlong fieldwork in 2000-01.

3. Other anthropologists (e.g., Sider 1987), following Morton Fried (1975), have analyzed the ways that colonizers and states create (through fantasy and coercive practice) the cultural groups that they then recognize as culturally distinctive. Gerald Sider emphasizes the contradiction between the state's incorporation and cultural distancing of the other.

4. Povinelli's research is based in Australia. Although Australia and the United States differ in many ways, they share the distinctive dilemmas of those democratic settler states with Anglophone legal traditions that struggle to reconcile ideals of equal citizenship with those of claims to political distinctiveness and different forms of citizenship by indigenous peoples. Of course, there are major differences among the Anglophone settler states. For example, Australia does not recognize Aboriginal sovereignty (although court rulings over Aboriginal land title have raised related questions and tensions). See Beckett 1988, Maaka and Fleras 2005, and Peterson and Sanders 1998.

5. Wealth can render a polity a tempting target for outside takeover, and the United States has a long history of appropriating the best of indigenous-held lands. Gaming is different because its economic value becomes worthless without the unique legal status of tribal sovereignty. As such, gaming shows need-based sovereignty to be distinguishable from resource extraction as explanations for why indigenous wealth might trigger curtailments of tribal sovereignty.

6. Jeremy Beckett's discussion of welfare colonialism shows how characterizations of Aboriginal Australians as poor compels state action to "solve" a "problem"; this, in turn, draws the state closer in a contradiction by which "the state is an integral part of the problem it is supposed to be solving" (Beckett 1988:4). See also Audra Simpson's discussion of Mohawk cigarette "smuggling," the regulation of indigenous economic practice, and settler characterizations of Iroquois "savagery" as lawlessness (Simpson 2008).

7. Here, it might be helpful to address one reviewer's suggestion that the double bind is less about economy than about autonomy and dependence. It is tempting to agree that the dynamic is one wherein if Indians can be autonomous and take care of themselves they cannot be sovereigns. This kind of analysis would fit well with dependency theories of tribal-state relations. However, elsewhere in my analysis of tribal gaming (Cattelino 2008), I have argued against understanding sovereignty as being based on autonomy, because I found sovereignty often to be forged in relations of interdependency. Moreover, gaming wealth can hardly be described as autonomous, because in Florida it relies for a consumer base almost entirely on non-Indians and because it more accurately would be described as market integration.

8. I am not making an ahistorical claim that need-based sovereignty is the one and only modality of settler colonialism in the United States, much less beyond. Although I offer examples from the late-19th century as well as termination and gaming, interim policies coupled the goal of achieving economic power with sovereign recognition. Counterexamples, each with complicating subtleties, include the Indian New Deal and Nixon's self-determination policy.

9. For histories of termination policy see Fixico 1986 and Philp 1999; for case studies, see Rosier 2001 on Blackfeet and Kersey 1996 on Florida Seminoles.

10. Collier's Indian Reorganization Act of 1934 sought to standardize tribal governments and reinforce cultural preservation by promoting constitutionalism, voting-based democracy, and economic development. That said, the IRA also was a standardizing initiative that brushed aside local variations in political form and process (Biolsi 1992).

11. For more on economy and termination policy, see Philp 1999 and Cattelino in press.

12. The Seminole wars were the costliest of the 19th-century Indian wars. Seminoles were part of Indian "removal" policy, by which they were sometimes convinced and sometimes forced to leave Florida for Indian Territory. Since removal, the Seminole Nation of Oklahoma and the Seminole Tribe of Florida have been separate polities, and this essay does not address 


cuan_1058 can2008.cls March 5, 2010 16:4

CULTURAL ANTHROPOLOGY 25:2

the Seminole Nation of Oklahoma. Florida Seminoles refer to themselves as "unconquered" because they survived the Seminole wars and never signed a peace treaty with the United States.

13. For a more ethnographic discussion of Seminole sovereignty, see Cattelino 2008.

14. Kersey (1996) has analyzed the reasons why Seminole were moved from the list of tribes who would be inappropriate for termination to the inaugural slate of terminated tribes. A major factor, he concludes, was the Florida delegation's eagerness to show support for termination because one of its own, Rep. James Haley, served as chairman of the House Subcommittee on Indian Affairs.

15. For general history, see Sturtevant and Cattelino 2004 and Covington 1993; for political history, see Kersey 1989, 1996.

16. A majority of Seminoles had met and passed the following resolution: "We, the Seminole Indians of Florida, request that no action be taken on the termination of Federal supervision over the property of the Seminole Indians for a period of 25 years" (U.S. Congress 1954: 1038).

17. See Bruyneel (2005:ch. 4) on Haudenosaunee efforts to refuse U.S. citizenship.

18. Paine, who brought a systems theory approach to thinking about Fourth World peoples, writes of how extending ordinary citizenship to them is not sufficient, and furthermore how "welfare programs . . . are a contemporary version of this historically familiar process whereby the anomalous status of 'native person' is transformed into one of client under tutelage" (Paine 1984:215). When the state tries to fit indigenous peoples into conventional citizenship regimes, they "fail" as state citizens, "and the state rationalizes this failure rate in terms of the ideology of welfarism” (Paine 1984:221). Such concerns over the relationship of citizenship to economic participation are not limited to settler-indigenous relations. For example, in conflicts over welfare reform and immigration, Americans debate whether work is necessary or sufficient, respectively, to enjoy the full benefits of citizenship.

19. Paul Rosier's study of Blackfeet efforts to forge beneficial relations with the federal government during this period shows that some Indian people supported termination on the basis of "Indian notions of 'self-support'" because it would liberate them from federal control over tribal governance (Rosier 2001:1-2; see also Castile 1998).

20. Elsewhere (Cattelino 2004:ch. 7), I have distinguished “overlapping citizenship” in indigenous and settler polities from dual citizenship in two nation states, for example Brazil and Canada. In 2009, the Seminole Tribal Council began to hold its meetings on the Brighton Reservation (the meetings rotate among reservations) in the new veterans' building, which is shaped like a star.

21. See Cattelino 2009 for an analysis of Seminole per capita payments and the politics of money's fungibility.

22. Donald Fixico notes that advocates generally saw termination as promoting civic egalitarianism, whereas many indigenous people viewed it as anti-Indian (Fixico 1986).

23. Indigenous economic organization, and more specifically the corporation, is the subject of an article-in-progress on Seminoles' acquisition of Hard Rock International. That article also addresses the role of corporations in the IRA and the Alaska Native Claims Settlement Act (ANCSA; Cattelino n.d.).

24. Compare to Beckett's discussion of how in Australia, after the 1960s partial dismantling of colonial structures of legal exclusion, Aboriginal "wellbeing would in practice depend on a special, collective relationship with the state," one in which "ironically, although no one may have intended it, the new dispensation provided a charter for Aborigines to live at a lower material level than other Australians: their poverty had been rendered exotic and so no longer comparable to other forms of poverty." Beckett calls this exoticization of poverty a "cultural screen” (Beckett 1988:12), which I take to be akin to Philip Deloria's "expectation.”

25. This followed on the heels of a mid-1970s foray into on-reservation cigarette sales that could be sold at a lower price because they were not taxed by the state. See Kersey 1996 and Cattelino 2008 .

26. One reviewer suggested that gaming was enabled by Public Law 280, which extended state criminal and civil jurisdiction (but not, courts held, taxation and regulation powers) into 
Indian Country within specified states (Goldberg-Ambrose 1975). It is true that several (but not all) early gaming tribes were located within Public Law 280 states, but this was not because of the law: arguably, it was a geographical circumstance driven by the fact that these tribal nations were located near major population centers. Gaming plausibly can be linked to P.L. 280 jurisprudence because the latter tested theories of tribal regulatory authority (Washburn 2008), but not directly to P.L. 280 incursions by the states. In an article about an important court case that clarified the limits of P.L. 280 state authority, legal scholar Kevin Washburn identified poverty as key to the court's reasoning in favor of tribal sovereignty: "The victory in Bryan may thus indirectly support the hypothesis that it is the moral high ground of poverty, not aggressive assertions of sovereignty, that has tended to account for past tribal victories in the Supreme Court" (Washburn 2008:966). I thank P.L. 280 expert Carole Goldberg for discussing this with me.

27. Self-determination was facilitated by Nixon-era federal policies that promoted tribal selfgovernance and economic development (Wilkins and Lomawaima 2005, Wilkinson 2005). Nixon was an important exception to need-based sovereignty because his rhetoric and policies made clear that sovereignty was not a function of poverty. Reagan, however, deployed similar language of sovereignty and local control to justify cutting federal funds for American Indian programs (Castile 2006).

28. Also see Jeffrey Dudas's (2005) discussion of the politics of resentment in struggles over American Indian hunting and fishing rights.

29. Bruyneel's focus here is time, whereas mine is economic difference. What brings the two together in termination and gaming alike is the modernist notion of progress.

30. See the discussion in Wilkins and Lomawaima (2001:230) of Justice Anthony Kennedy's skepticism in Kiowa Tribe of Oklahoma v. Manufacturing Technologies, Inc. (118 S.Ct. 1700 [1998]) about maintaining tribal sovereignty immunity when tribes "take part in the Nation's commerce." This was by no means the first time that Indian rights have been measured by need or means. Historian Alexandra Harmon generously pointed me to a U.S. Supreme Court case that imposed a "moderate living" limit on Indian treaty rights. In a fishing rights case, the Court held that a treaty secures "so much as, but no more than, is necessary to provide the Indians with a livelihood - that is to say, a moderate living" (Washington v. Washington State Commercial Passenger Fishing Vessel Association, 443 U.S. 658 [1979]). Harmon discusses this holding in chapter 6 of her manuscript on the history of American Indian wealth (Harmon n.d.).

31. Kirk Dombrowski (2001) has examined the relationships among political economy, cultural claims, and marginalization in Southeast Alaskan Native communities. He shows that industrial timber interests have supported Alaskan Native political recognition in the name of resource development, and he rightly argues that forces of state and capital have aligned to support indigenous recognition (I would only emphasize that this "works" because the discourse of indigenous poverty so effectively paves the way for development [see also Ferguson 1994]). Moreover, he helpfully calls attention to the costs for poor Native people of state demands that indigenous peoples stake claims in cultural terms. Still, the ways that indigeneity and poverty interlink suggest that there is another twist to his argument that "where people are both poor and native, collective struggles have centered more on claims attributable to nativeness than on those that come from being poor" (Dombrowski 2001:67). Fred Myers' study of the "scandals of commodification" (2002) in Australian Aboriginal fine art markets offers one way to think about the distinctive dilemmas of economic form and cultural production that are characteristic of settler societies.

32. In "Disappointing Indigenous People: Violence and the Refusal of Help," Gillian Cowlishaw (2003:111) has written about the unsettling effects of Aboriginal refusals to accept settler offers of financial or other forms of assistance: "Rejecting our proffered solutions to their problems could be seen as a way in which Indigenous people assert their autonomy from the state's suffocating solicitude."

33. Perhaps it is no coincidence that Philip Deloria's (2004) chapters about "Indians in Unexpected Places" tend to focus on sites of creativity, including music, acting, sports, and Indians' mobility behind the wheel of vehicles. 
cuan_1058 can2008.cls $\quad$ March 5, $2010 \quad 16: 4$

CULTURAL ANTHROPOLOGY 25:2

34. Alexandra Harmon (n.d.) is writing a welcome and necessary book about the history of indigenous wealth and its perception in the United States.

Editors Note: Cultural Anthropology has published a number of essays that examine how indigenous groups have been positioned in the United States. See Pauline Turner Strong and Barrik Van Winkle's “Indian Blood” (1996); Theresa D. O'Nell's “Telling about Whites, Talking about Indians" (1994); and Sara Ciborski and Gail Landsman's "Representation and Politics: Contesting Histories of the Iroquois" (1992). Cultural Anthropology has also published a wide range of essays that examine indigeneity more generally. See, for example, Andrea Muehlebach's “'Making Place' at the United Nations" (2001); Hane Veber's "The Salt of the Montaña: Interpreting Indigenous Activism in the Rain Forest" (1998); Faye Ginsburg's "Embedded Aesthetics: Creating a Discursive Space for Indigenous Media" (1994) and Liisa Malkki's "National Georgaphic: The Rooting of Peoples and the Territorialization of National Identity among Scholars and Refugees” (1992).

\section{REFERENCES CITED}

Aleinikoff, T. Alexander

2002 Semblances of Sovereignty: The Constitution, the State, and American

Barker, Joanne Citizenship. Cambridge, MA: Harvard University Press.

2005 For Whom Sovereignty Matters. In Sovereignty Matters: Locations of Contestation and Possibility in Indigenous Struggles for Self-Determination. J. Barker, ed. Pp. 1-31. Lincoln: University of Nebraska Press.

2005-06 Recognition. Special joint issue, "Indigenous Studies Today: Indigeneity at the Crossroads of American Studies," of Indigenous Nations Journal 1(Fall-Spring) and American Studies 46(3-4):133-161.

Bateson, Gregory

1972 Steps to an Ecology of Mind. New York: Ballantine.

Beckett, Jeremy

1988 Aboriginality, Citizenship, and the Nation State. Social Analysis 24:3-18.

Biolsi, Thomas

1992 Organizing the Lakota: The Political Economy of the New Deal on the Pine Ridge and Rosebud Reservations. Tucson: University of Arizona Press.

2005 Imagined Geographies: Sovereignty, Indigenous Space, and American Indian Struggle. American Ethnologist 32(2):239-259.

Blu, Karen I.

2001 Region and Recognition: Southern Indians, Anthropologists, and Presumed Biology. In Anthropologists and Indians in the New South. R. A. Bonney, J. A. Paredes, and R. D. Fogelson, eds. Pp. 27-51. Tuscaloosa: University of Alabama Press.

Bruyneel, Kevin

2007 The Third Space of Sovereignty: The Postcolonial Politics of U.S.-Indigenous Relations. Minneapolis: University of Minnesota Press.

Castile, George Pierre

1998 To Show Heart: Native American Self-Determination and Federal Indian Policy, 1960-1975. Tucson: University of Arizona Press.

2006 Taking Charge: Native American Self-Determination and Federal Indian Policy, 1975-1993. Tucson: University of Arizona Press.

Cattelino, Jessica R.

2004 High Stakes: Seminole Sovereignty in the Casino Era. Ph.D. dissertation, Department of Anthropology, New York University.

2006 Florida Seminole Housing and the Social Meanings of Sovereignty. Comparative Studies in Society and History 48(3):699-726. 
2008 High Stakes: Florida Seminole Gaming and Sovereignty. Durham, NC: Duke University Press.

2009 Fungibility: Florida Seminole Casino Dividends and the Fiscal Politics of Indigeneity. American Anthropologist 111(2):190-200.

In press Termination Redux? Seminole Citizenship and Economy from Truman to Gaming. In Harry Truman and Native Americans. B. Hosmer, ed. Kirksville, MO: Truman State University Press.

N.d. "One Hamburger at a Time": Revisiting the State-Society Divide with the Seminole Tribe of Florida and Hard Rock International. Unpublished MS, Department of XXXX, University of XXXX.

Ciborski, Sara, and Gail Landsman

1992 Representation and Politics: Contesting Histories of the Iroquois. Cultural Clifford, James Anthropology 7(4):425-447.

1988 Identity in Mashpee. In The Predicament of Culture: Twentieth-Century Ethnography, Literature, and Art. Pp. 277-346. Cambridge, MA: Harvard University Press.

Covington, James W.

1993 The Seminoles of Florida. Gainesville: University Press of Florida.

Cowlishaw, Gillian

2003 Disappointing Indigenous People: Violence and the Refusal of Help. Public Culture 15(1):103-125.

Cramer, Renée Ann

2005 Cash, Color, and Colonialism: The Politics of Tribal Acknowledgment. Norman: University of Oklahoma Press.

Darian-Smith, Eve

2003 New Capitalists: Law, Politics, and Identity Surrounding Casino Gaming Deloria, Philip J. on Native American Land. Belmont, CA: Wadsworth-Thomson Learning.

2004 Indians in Unexpected Places. Lawrence: University Press of Kansas.

Deloria, Sam

2002 Commentary on Nation-Building: The Future of Indian Nations. Arizona

Deloria, Vine, Jr. State Law Journal 34:55-62.

1979 Self-Determination and the Concept of Sovereignty. In Economic Development in American Indian Reservations. R. D. Ortiz, ed. Pp. 22-28. Albuquerque: University of New Mexico Native American Studies.

Deloria, Vine, Jr., and Clifford M. Lytle

1984 The Nations within: The Past and Future of American Indian Sovereignty. New York: Pantheon.

Dombrowski, Kirk

2001 Against Culture: Development, Politics, and Religion in Indian Alaska.

Dudas, Jeffrey R. Lincoln: University of Nebraska Press.

2005 In the Name of Equal Rights: "Special” Rights and the Politics of Resentment in Post-Civil Rights America. Law and Society Review 39(4):723-757.

Fischer, Michael M. J.

2003 Emergent Forms of Life and the Anthropological Voice. Durham, NC: Duke University Press.

Fixico, Donald Lee

1986 Termination and Relocation: Federal Indian Policy, 1945-1960. Albuquerque: University of New Mexico Press.

Fried, Morton H.

1975 The Notion of Tribe. Menlo Park, CA: Cummings. 
cuan_1058 can2008.cls March 5, $2010 \quad 16: 4$

CULTURAL ANTHROPOLOGY 25:2

Ferguson, James

1994 The Anti-Politics Machine: "Development," Depoliticization, and Bureau-

Ginsburg, Faye cratic Power in Lesotho. Minneapolis: University of Minnesota Press.

1994 Embedded Aesthetics: Creating a Discursive Space for Indigenous Media. Cultural Anthropology 9(3):365-382.

Goldberg-Ambrose, Carole

1975 Public Law 280: State Jurisdiction Over Reservation Indians. UCLA Law Review 22:535-594.

Harmon, Alexandra

N.d. Wealth, Indians, and Morality in American History. Unpublished MS, Departments of American Indian Studies and History, University of Washington.

Kersey, Harry A., Jr.

1989 The Florida Seminoles and the New Deal, 1933-1942. Boca Raton: Florida Atlantic University Press.

1996 An Assumption of Sovereignty: Social and Political Transformation among the Florida Seminoles, 1953-1979. Lincoln: University of Nebraska Press.

Kymlicka, Will

1995 Multicultural Citizenship. Oxford: Oxford University Press.

Maaka, Roger, and Augie Fleras

2005 The Politics of Indigeneity: Challenging the State in Canada and Aotearoa New Zealand. Dunedin, New Zealand: University of Otago Press.

Malkki, Liisa

1992 National Geographic: The Rooting of Peoples and the Territorialization of National Identity among Scholars and Refugees. Cultural Anthropology $7(1): 24-44$

Marshall, T. H.

1992 [1950] Citizenship and Social Class. London: Pluto.

Morgan, Lewis Henry

1974 [1877] Ancient Society. Gloucester, MA: Peter Smith.

Muehlebach, Andrea

2001 "Making Place" at the United Nations: Indigenous Cultural Politics at the U.N. Working Group on Indigenous Populations. Cultural Anthropology $16(3): 415-448$.

Myers, Fred

2002 Painting Culture: The Making of Aboriginal High Art. Durham, NC: Duke University Press.

O’Nell, Theresa D.

1994 Telling about Whites, Talking about Indians: Oppression, Resistance, and Paine, Robert Contemporary American Indian Identity. Cultural Anthropology 9(1):94-126.

1977 The Path to Welfare Colonialism. In The White Arctic: Anthropological Essays on Tutelage and Ethnicity. R. Paine, ed. Pp. 3-28. St. John's: Memorial University of Newfoundland.

1984 Norwegians and Saami: Nation-State and Fourth World. In Minorities and Mother Country Imagery. G. Gold, ed. Pp. 211-248. Social and Economic Papers, 13. St. John's: Memorial University of Newfoundland, Institute of Social and Economic Research.

1999 Aboriginality, Multiculturalism, and Liberal Rights Philosophy. Ethnos 64(3):325-349.

Peterson, Nicolas, and Will Sanders, eds.

1998 Citizenship and Indigenous Australians: Changing Conceptions and Possibilities. Cambridge: Cambridge University Press. 
Philp, Kenneth R.

1999 Termination Revisited: American Indians on the Trail to Self-Determination, 1933-1953. Lincoln: University of Nebraska Press.

Povinelli, Elizabeth A.

2002 The Cunning of Recognition: Indigenous Alterities and the Making of Rosier, Paul C. Australian Multiculturalism. Durham, NC: Duke University Press.

2001 Rebirth of the Blackfeet Nation, 1912-1954. Lincoln: University of Nebraska Press.

Sahlins, Marshall

1993 Cosmologies of Capitalism: The Trans-Pacific Sector of "The World System.” In Culture/Power/History: A Reader in Contemporary Social Theory. Nicholas B. Dirks, Geoff Eley, and Sherry B. Ortner, eds. Pp. 412-455. Princeton: Princeton University Press.

Sider, Gerald

1987 When Parrots Learn to Talk, and Why They Can't: Domination, Deception, and Self-Deception in Indian-White Relations. Comparative Studies in Society and History 29(1):3-23.

2003 Living Indian Histories: Lumbee and Tuscarora People in North Carolina. Chapel Hill: University of North Carolina Press.

Simpson, Audra

2003 To the Reserve and Back Again: Kahnawake Mohawk Narratives of Self, Home and Nation. Ph.D. dissertation, Department of Anthropology, McGill University.

2007 On Ethnographic Refusal: Indigeneity, "Voice" and Colonial Citizenship. Junctures 9:67-80.

2008 Subjects of Sovereignty: Indigeneity, the Revenue Rule, and Juridics of Failed Consent. Law and Contemporary Problems 71:191-215.

Spilde, Katherine A.

2004 Creating a Political Space for American Indian Economic Development: Indian Gaming and American Indian Activism. In Local Actions: Cultural Activism, Power, and Public Life in America. M. Checker and M. Fishman, eds. Pp. 71-88. New York: Columbia University Press.

Strong, Pauline Turner, and Barrik Van Winkle

1996 "Indian Blood": Reflections on the Reckoning and Refiguring of Native North American Identity. Cultural Anthropology 11(4):547-576.

Sturtevant, William C., and Jessica R. Cattelino

2004 Florida Seminole and Miccosukee. In Handbook of North American Indians (Southeast), vol. 14. Raymond D. Fogelson, ed. Pp. 429-449. Washington, DC: Smithsonian Institution Press.

Taylor, Jonathan B., and Joseph P. Kalt

2005 American Indians on Reservations: A Databook of Socioeconomic Change between the 1990 and 2000 Censuses. Cambridge, MA: Harvard Project on American Indian Economic Development, Harvard University.

U.S. Congress

1954 Termination of Federal Supervision over Certain Tribes of Indians, Part 8, Seminole Indians, Florida. Joint Hearing before the Subcommittees of the Committees on Interior and Insular Affairs. Eighty-Third Congress of the United States. Washington, DC: Government Printing Office.

1955 Seminole Indians, Florida, Hearings Pursuant to H. Res. 30. House Subcommittee on Indian Affairs. Eighty-Fourth Congress House of Representatives. Washington, DC: Government Printing Office.

Veber, Hanne

1998 The Salt of the Montaña: Interpreting Indigenous Activism in the Rain Forest. Cultural Anthropology 13(3):382-413. 
cuan_1058 can2008.cls March 5, $2010 \quad 16: 4$

CULTURAL ANTHROPOLOGY 25:2

Washburn, Kevin K.

2008 The Legacy of Bryan v. Itasca County: How an Erroneous $\$ 147$ County Tax Notice Helped Bring Tribes \$200 Billion in Indian Gaming Revenue. Minnesota Law Review 92(4):919-970.

Wilkins, David E., and K. Tsianina Lomawaima

2001 Uneven Ground: American Indian Sovereignty and Federal Law. Norman: University of Oklahoma Press.

Wilkinson, Charles

2005 Blood Struggle: The Rise of Modern Indian Nations. New York: W. W. Norton. 
cuan_1058 can2008.cls March 5, $2010 \quad 16: 4$

\section{Query}

Q1 Author: Please supply the department and affiliation under which this work was primarily composed. 